\title{
The Primates 2009 Most-Cited Paper Award is conferred upon Dr. Andrew J. Plumptre
}

(C) Japan Monkey Centre and Springer 2009

The paper by Dr. Andrew J. Plumptre (with Dr. Debby Cox) titled "Counting primates for conservation: primate surveys in Uganda" was the most frequently cited of the papers published in Primates between 2006 and 2007 . His work thus contributed greatly to enhancing the reputation of our journal. For his achievement, Dr. Plumptre will receive a certificate and gifts from the Japan Monkey Centre, Springer, and the Primate Society of Japan.

19 July 2009

Juichi Yamagiwa: President, Primate Society of Japan

Ryoji Fukada: Managing Director, Springer Japan

Toshisada Nishida: Executive Director, Japan Monkey Centre 